\title{
Simulation of the Fast Pyrolysis of Coffee Ground in a Tilted-Slide Reactor
}

\author{
Sang Kyu Choi ${ }^{1,2, *}$, Yeon Seok Choi ${ }^{1,2}$, Yeon Woo Jeong ${ }^{1}$, So Young Han ${ }^{1 \oplus}$ and \\ Quynh Van Nguyen ${ }^{2}$ \\ 1 Department of Clean Fuel \& Power Generation, Korea Institute of Machinery \& Materials, \\ 156 Gajeongbuk-ro, Yuseong-gu, Daejeon 34103, Korea; yschoi@kimm.re.kr (Y.S.C.); \\ ywjeong@kimm.re.kr (Y.W.J.); syhan@kimm.re.kr (S.Y.H.) \\ 2 Environment \& Energy Mechanical Engineering, University of Science and Technology, 217 Gajeong-ro, \\ Yuseong-gu, Daejeon 34113, Korea; josquynhnv@kimm.re.kr \\ * Correspondence: skchoi4091@kimm.re.kr; Tel.: +82-42-868-7398
}

Received: 12 November 2020; Accepted: 10 December 2020; Published: 14 December 2020

check for updates

\begin{abstract}
The fast pyrolysis of coffee ground for bio-crude oil production was simulated in a tilted-slide reactor. The biochemical composition was derived by an extended biomass characterization method based on the elemental analysis. The simulation was performed in a steady-state and a Lagrangian multiphase model was adopted to describe the transport of sand and biomass particles together with a multistep kinetic mechanism for fast pyrolysis. When the secondary tar cracking reactions were not considered the volatile yield increased monotonically with temperature. The inclusion of secondary reactions could improve the prediction of volatile yield which turn to decrease at higher temperature. It was found that not only the maximum volatile yield but also the corresponding reactor temperature agreed well with the experimental results. At the temperature higher than $550^{\circ} \mathrm{C}$ the trend of volatile yield is similar to that of experiment while it is larger at lower reactor temperature. The individual species yields were compared at various reactor temperatures and the pyrolysis processes were analyzed by tracking the reference components when they were decomposed along the distance. It was found that the reactor temperature should be above $500^{\circ} \mathrm{C}$ for effective pyrolysis of all reference components of coffee ground.
\end{abstract}

Keywords: fast pyrolysis; coffee ground; bio-crude oil; tilted-slide reactor; simulation

\section{Introduction}

Utilizing biomass as a renewable energy source has been widely studied to cope with the global warming issue and the depletion of fossil fuels. Although direct combustion of biomass in a solid form is the simplest application method as an energy source, converting biomass into a liquid fuel has advantages in storage and transportation due to the increase of energy density. Fast pyrolysis is a thermochemical process to convert biomass into liquid fuel [1-4] and this liquid product is commonly named as bio-oil or bio-crude oil. In the fast pyrolysis process, biomass is quickly decomposed into gas and solid phase in oxygen-free environment and the bio-crude oil can be obtained by quenching the gas-phase product. The optimum condition for the maximum bio-crude oil yield is known to be around $500{ }^{\circ} \mathrm{C}$. There have been developed various pyrolysis reactors [5-9] and fluidized bed reactors have been widely adopted ranging from lab scale to commercial scale. For the efficient design, scale-up and optimization of the pyrolysis reactor, it is important to understand the fast pyrolysis process in detail. There have been numerical studies on the fast pyrolysis in bubbling fluidized bed reactors [10-16], entrained flow reactors [17-19] and spouted bed reactors [20-22]. The pyrolysis kinetics also have been developed extensively including the biomass characterization method [23-27]. 
Recently, a tilted-slide reactor has been developed for efficient process of fast pyrolysis $[9,28,29]$. In this reactor, hot sand descends from the top of the tilted reactor where the biomass is supplied separately. The biomass is transported downward together with the sand by the gravity force and is pyrolyzed during this decent. Because no fluidization gas is required in this reactor, the plant size and operation cost can be reduced in comparison with fluidized bed reactors. Various kinds of biomass feedstock have been tested in the tilted-slide reactor including sawdust, coffee ground and palm kernel shell $[9,28-30]$.

The numerical study of a tilted-slide reactor has been also performed for the fast pyrolysis of sawdust biomass in a previous study [31]. The biomass composition has been characterized to specify the ratio of cellulose, hemicellulose and lignin as reference components based on the elemental composition and a multistep kinetic mechanism developed by Ranzi et al. [23-27] has been adopted for the pyrolysis simulation. The particle behaviors of sand and sawdust have been tracked and the chemical process of sawdust pyrolysis has been analyzed in detail. It was observed that the bio-crude oil yield increased monotonically with temperature which was different from the experimental results due to the absence of the secondary tar cracking reactions in the simulation. It is known that the secondary gas-phase reactions for tar cracking becomes important at high temperatures [24,25,32] and the noncondensable gases are increased from the volatile decomposition. Their effects have been accounted for in an indirect way with 1-D simulation using the reactor outlet composition due to the complexity of the gas-phase kinetics which could be hardly applied in the 3-D reactor simulation directly.

In this study, the fast pyrolysis of coffee ground in a tilted-slide reactor was investigated by numerical simulation. There is a growing attention to utilizing coffee ground as a new biomass resource due to its increase of consumption worldwide [33]. The experimental study on the fast pyrolysis of coffee ground in a tilted-slide reactor has shown that the maximum oil yield was $59 \%$ at the temperature of $550{ }^{\circ} \mathrm{C}$ with the feeding rate of $17.7 \mathrm{~kg} / \mathrm{h}$ [29]. The prediction of product yields was focused on in this study at various reactor temperatures. As a first step for the simulation, the biochemical composition of coffee ground was specified by adopting an extended biomass characterization method [26] to include the extractives which was not negligible in coffee ground differing from sawdust biomass. To improve the prediction of the bio-crude oil yield at various reaction temperature without much computational cost, the detailed secondary gas-phase reactions were simplified and then were imposed in the 3-D reactor simulation directly. The product yields were compared with the experimental results at various reactor temperatures and the species distribution and the behaviors of pyrolyzing particles were also analyzed in detail.

\section{Numerical Simulation}

\subsection{Characterization of the Coffee Ground Composition}

For modeling the thermal degradation of biomass particle, it is important to determine the biomass composition because biomass consists of various species which show different pyrolyzing pathways. The major components which constitute biomass are generally cellulose, hemicellulose and lignin. Extractive species, protein and ash can be other minor components. But detailed information of biochemical composition which can provide the relative amount of these components is not commonly available because there still remain difficulties and uncertainties in current measurement techniques. To overcome this problem, an alternative approach has been suggested by Ranzi et al. [23] to derive the biomass composition in an indirect way based on the $\mathrm{C} / \mathrm{H} / \mathrm{O}$ atomic balance of biomass. In the previous study on the sawdust pyrolysis in a tilted-slide reactor [31], five reference components have been adopted to represent cellulose, hemicellulose and three different types of lignins. Figure 1 shows these reference species in the $\mathrm{H} / \mathrm{C}$ diagram. The reference components CELL represent the cellulose monomer $\left(\mathrm{C}_{6} \mathrm{H}_{10} \mathrm{O}_{5}\right)$. The hemicellulose is represented as a reference component HECELL which is approximated to be a xylose monomer $\left(\mathrm{C}_{5} \mathrm{H}_{8} \mathrm{O}_{4}\right)$. Because lignin has a complex chemical structure, three reference 
components of LIG-C $\left(\mathrm{C}_{15} \mathrm{H}_{14} \mathrm{O}_{4}\right)$, LIG-H $\left(\mathrm{C}_{22} \mathrm{H}_{28} \mathrm{O}_{9}\right)$ and LIG-O $\left(\mathrm{C}_{20} \mathrm{H}_{22} \mathrm{O}_{10}\right)$ were adopted which are richer in $\mathrm{C}, \mathrm{H}$ and $\mathrm{O}$, respectively. The three reference mixtures, $\mathrm{RM}-1, \mathrm{RM}-2$ and $\mathrm{RM}-3$ are specified to reduce the degree of freedom in the biomass characterization. These reference mixtures are defined by the splitting parameters, $\alpha, \beta$ and $\gamma$. The mixture RM- 1 is composed of $60 \%$ CELL and $40 \%$ HECELL in molar ratio where $\alpha$ is defined to be 0.6. RM-2 and RM-3 are composed of $80 \%$ LIG-H and $20 \%$ LIG-C $(\beta=0.8)$ and 80\% LIG-O and 20\% LIG-C $(\gamma=0.8)$, respectively. These reference mixtures RM-1, RM-2 and RM-3 form the vertices of the dark-shadowed triangle of Figure 1 . When the elemental composition of biomass is placed inside this triangle, its biochemical composition can be derived from a linear combination of RM-1, RM-2 and RM-3. The sawdust biomass in the previous study falls within the triangle as represented to be 'SD' in Figure 1 and the five reference components are sufficient for biomass characterization.

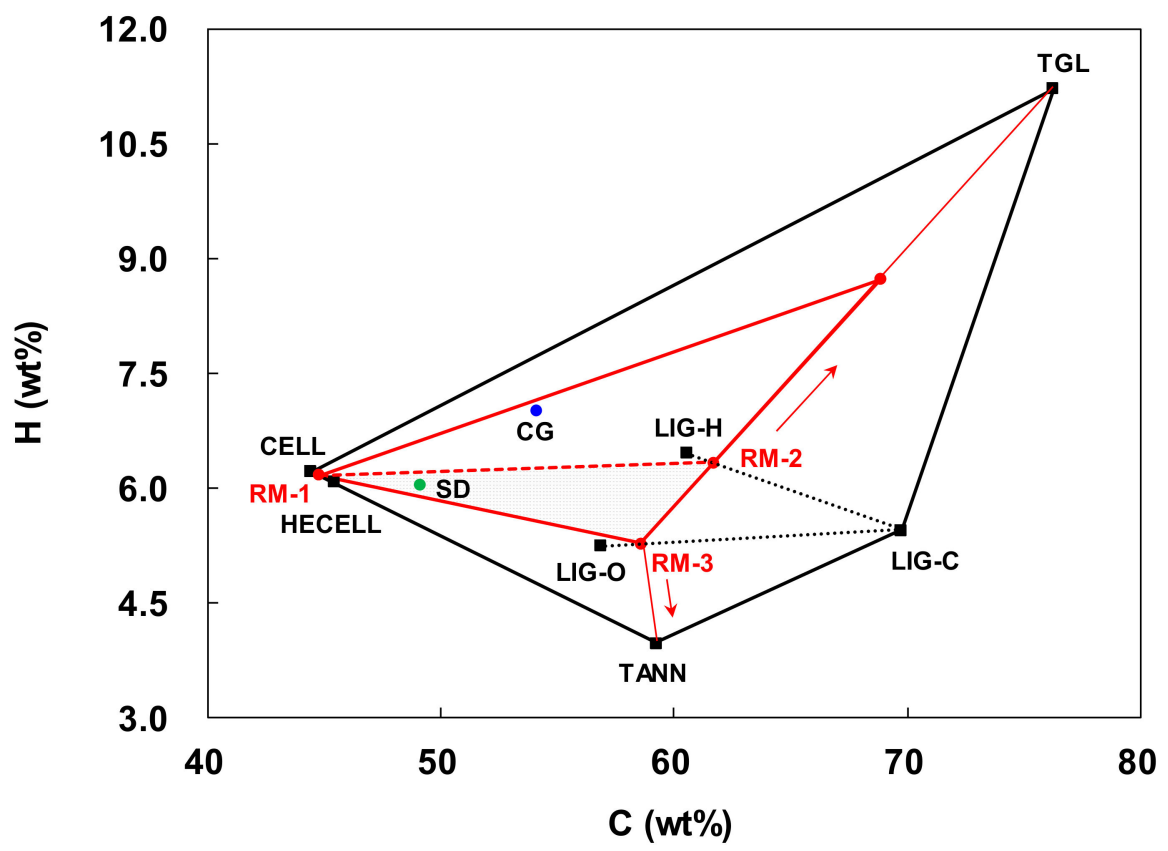

Figure 1. Biomass characterization from elemental analysis.

The coffee grounds have been collected from coffee shops in Seoul, South Korea. The moisture content of collected coffee ground was higher than $50 \mathrm{wt} \%$ and it should be dried prior to fast pyrolysis. The coffee ground was dried in a rotary dryer to lower its moisture content down to less than $10 \mathrm{wt} \%$. We note that the drying process only evaporates the water in coffee ground without changing its chemical structure and the drying pretreatment could only affect the water content in bio-crude oil. Table 1 shows the result of proximate analysis for coffee ground. The proximate analysis was performed using a thermogravimetric analyzer (LECO TGA 701). Because the moisture and ash contents are not negligible in coffee ground, their effects were included in the simulation which will be discussed later in detail. Table 2 shows the elemental composition of coffee ground. The elemental composition was measured by an elemental analyzer (Flash EA 1112 series). For the biomass characterization, the $\mathrm{C} / \mathrm{H} / \mathrm{O}$ ratios were normalized to make their sum to be $100 \%$ in dry and ash-free basis. The elemental composition of coffee ground indicated by ' $\mathrm{CG}^{\prime}$ in Figure 1 falls outside the dark-shadowed triangle formed by RM-1, RM-2 and RM-3. It can be known that coffee ground has larger C and $\mathrm{H}$ contents in comparison with sawdust and it cannot be represented by the five reference species (CELL, HECELL, LIG-C, LIG-H and LIG-O). It is known that several kinds of softwoods, grass plants and seeds are relatively rich in extractive species and the area of biomass characterization needs to be extended by introducing new reference components [26]. Because there is a great variety of the extractive species, a couple of lumped species were introduced for simplification depending on their water solubility, that is, hydrophobic and hydrophilic extractives. For hydrophobic extractives, triglycerides which 
have large amount of linoleic acid are most common. Based on this, a reference component named TGL $\left(\mathrm{C}_{57} \mathrm{H}_{100} \mathrm{O}_{7}\right)$ with large $\mathrm{C}$ and $\mathrm{H}$ content was selected [26] as marked in Figure 1. For hydrophilic species, phenolic compounds are typical which can be represented by tannin species. The component named TANN $\left(\mathrm{C}_{15} \mathrm{H}_{12} \mathrm{O}_{7}\right)$ with a small $\mathrm{H}$ amount was selected [26] as indicated in Figure 1.

Table 1. Proximate analysis (wt $\%$ ) of coffee ground (wet basis).

\begin{tabular}{cccc}
\hline Moisture & Volatile & Fixed Carbon & Ash \\
\hline 6.10 & 72.22 & 18.91 & 2.77 \\
\hline
\end{tabular}

Table 2. Elemental composition (wt $\%$ ) of coffee ground (dry and ash-free basis).

\begin{tabular}{ccccc}
\hline $\mathbf{C}$ & $\mathbf{H}$ & $\mathbf{O}{ }^{*}$ & $\mathbf{N}$ & $\mathbf{S}$ \\
\hline 52.54 & 6.83 & 37.79 & 2.84 & 0 \\
\hline \multicolumn{5}{c}{ * By difference. }
\end{tabular}

The biomass characterization can be extended significantly by introducing new species of TGL and TANN. The inclusion of TGL in RM-2 can cover the biomass richer in hydrogen, while the biomass with lower hydrogen content can be characterized by the inclusion of TANN in RM-3. The new splitting parameter $\delta$ defines the molar ratio of lignins (LIG-H and LIG-C) in RM-2, which also means that the molar ratio of TGL in RM-2 is $1-\delta$. Another splitting parameter $\varepsilon$ defines the molar ratio of lignins (LIG-O and LIG-C) in RM-3 which means that the molar ratio of TANN in RM-3 is 1- $\varepsilon$. Because coffee ground is richer in carbon and hydrogen, it is enough to migrate the vertex RM-2 in the direction of TGL, while the location of RM-3 need not to be modified. The splitting parameters $\alpha / \beta / \gamma / \delta / \varepsilon=0.6 / 0.8 / 0.8 / 0.7 / 1$ can successfully extend the characterization region to light-shadowed area to cover coffee ground as shown in Figure 1. The biochemical composition is then derived as shown in Table 3 by adding moisture and ash which were determined from the proximate analysis.

Table 3. Characterization of coffee ground.

\begin{tabular}{cc}
\hline Species & Mass Fraction \\
\hline CELL & 0.3487 \\
HECELL & 0.1894 \\
LIG-H & 0.1431 \\
LIG-O & 0.0444 \\
LIG-C & 0.0280 \\
TGL & 0.1577 \\
Moisture & 0.0610 \\
Ash & 0.0277 \\
\hline
\end{tabular}

\subsection{Simulation Method}

The fast pyrolysis of coffee ground had been performed in a tilted-slide reactor [29]. The schematic diagram of the reactor system is shown in Figure 2. The biomass is supplied via a screw conveyor into the top of the tilted reactor. The heated sand is also supplied to the top of the reactor as a heat transfer medium for fast pyrolysis. The biomass is pyrolyzed while it is transported down together with hot sand and their movements are guided baffles installed on the reactor floor. The pyrolysis products are gaseous species and residual char. The gaseous products are composed of condensable volatiles and noncondensable gases, which pass though the condensers where the volatiles are condensed into bio-crude oil. The solid residue is biochar and it is conveyed with sand from the reactor bottom to the circulating fluidized bed combustor where the biochar is burned to heat up the sand. In the tilted-slide reactor, the oxygen-free condition for the fast pyrolysis can be maintained due to the sand filled in the sand hopper above the reactor and that filled in the screw conveyer below the reactor. In this study, as the simulation region the tilted reactor is focused on and the condensation of 
volatile was not accounted for. Therefore, it is assumed that the yield of bio-crude oil is equivalent to that of volatile. The simulation is carried out using a commercial computational fluid dynamics software (STAR-CCM+ v9.06). The geometry for the simulation is shown in Figure 3 together with the trimmer mesh with rectangular cuboid shape. The meshes were composed of 40,113 cells. During the experiment, the reactor is operated at a slightly negative pressure condition by the induced draft fan to prevent a leak of pyrolytic gas from the reactor. The effect of induced draft fan is implemented by introducing a fan interface as indicated in Figure 3. The fan performance curve provided by the fan manufacturer is applied to the simulation and the fan rotation rate is specified at $286 \mathrm{rpm}$ which corresponds to $5 \mathrm{~Hz}$ of the inverter to control the fan rotation rate in the experiment.

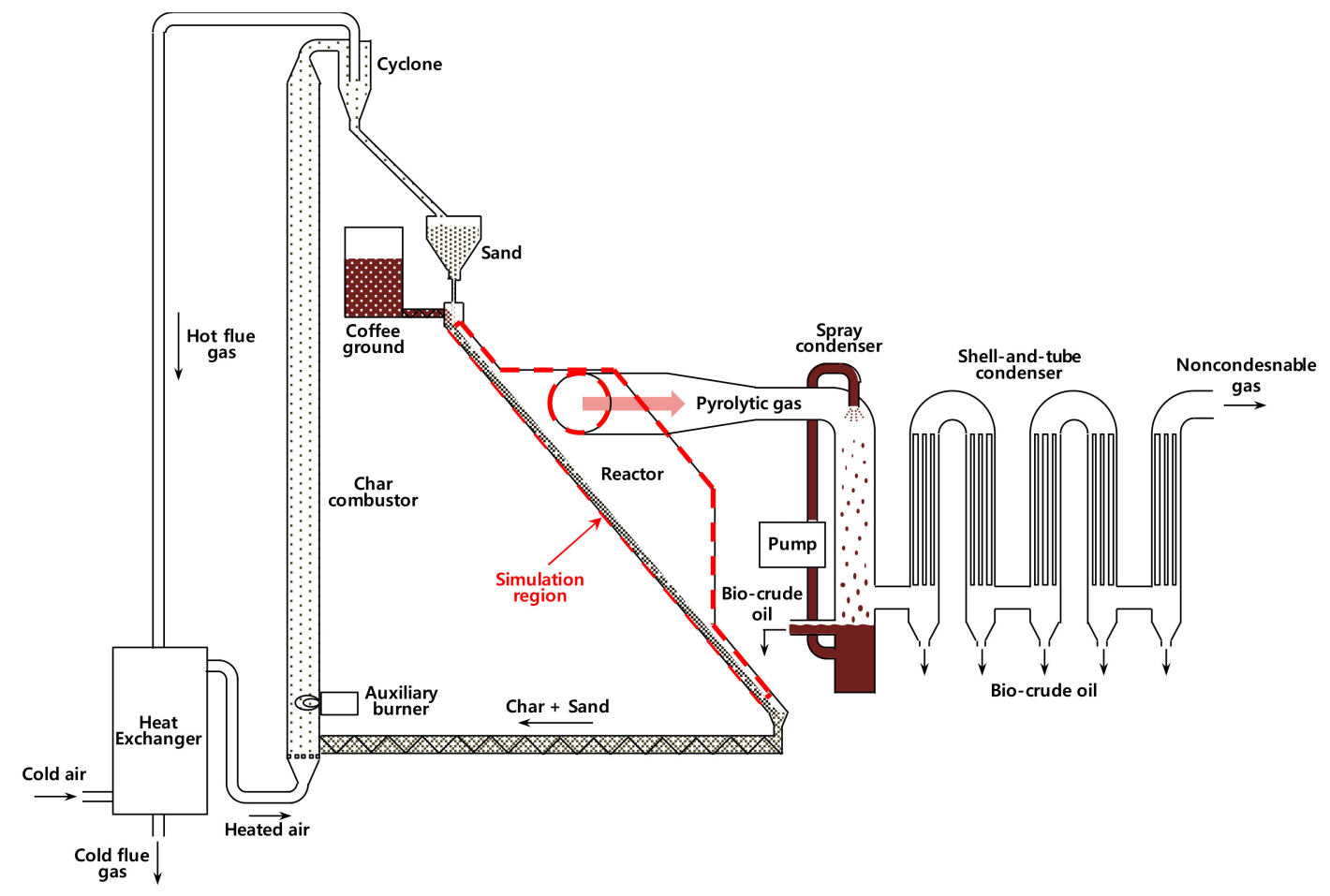

Figure 2. Schematic diagram of the tilted-slide fast pyrolyzer.

The governing equations of continuity, momentum, energy and species equations were discretized by finite volume method and the segregated approach was used to solve the flow equations. The details of governing equations and solving procedure are described in previous study [31] and STAR-CCM+ user guide [34]. To simulate the behaviors of sand and biomass particles, a Lagrangian multiphase model is adopted. The densities of sand and coffee ground were 2650 and $1145 \mathrm{~kg} / \mathrm{m}^{3}$, respectively. The specific heat of sand is evaluated by a polynomial as a function of temperature to be $c_{p}=318.3+1.612 \mathrm{~T}-5.634 \times 10^{-4} \mathrm{~T}^{2}$. The specific heats of coffee ground and biochar are treated separately, which are calculated to be $c_{p}=-919.3+0.087 \mathrm{~T}-6.723 \times 10^{-3} \mathrm{~T}^{2}-2.063 \times 10^{-6} \mathrm{~T}^{3}$ and $c_{p}=-1989+14.87 T-2.445 \times 10^{-2} T^{2}+1.847 \times 10^{-5} T^{3}-5.195 \times 10^{-9} T^{4}$, respectively. The residence time of sand particle was measured to be $4.5 \mathrm{~s}$ at the atmospheric condition. In the simulation, the normal and tangential restitution coefficients of particles are selected to be 0.8 by trial and error to have a similar residence time. 


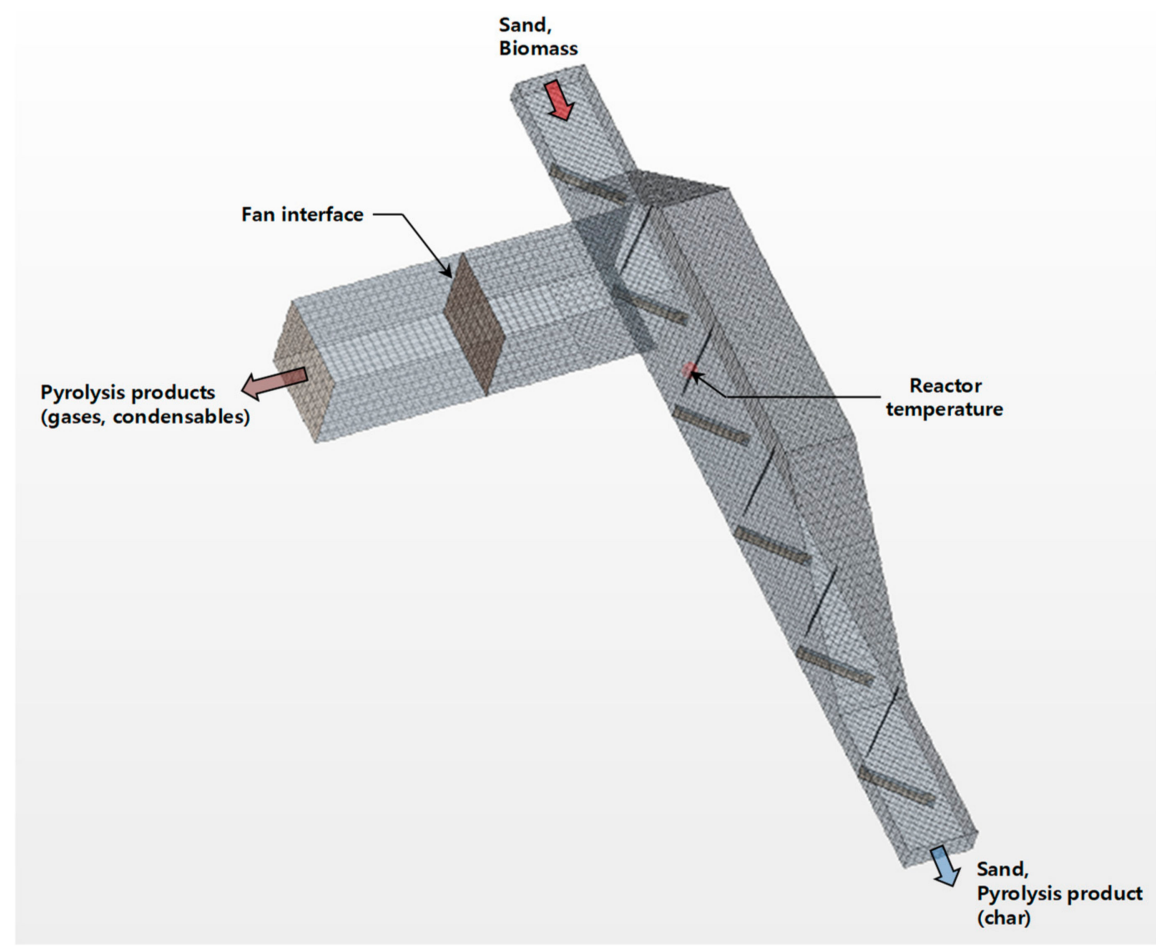

Figure 3. Calculation domain and mesh.

The fluid-particle heat transfer is calculated using the Nusselt number with the expression from Gunn as follows [35]:

$$
\mathrm{Nu}_{p}=\left(7-10 e+5 e^{2}\right)\left(1+0.7 \operatorname{Re}_{p}^{0.2} \operatorname{Pr}^{1 / 3}\right)+\left(1.33-2.4 e+1.2 e^{2}\right) \operatorname{Re}_{p}^{0.7} \operatorname{Pr}^{1 / 3},
$$

where $e$ is the volume fraction of gas-phase. It is known that this expression is more suitable for a wide range of particle volume fractions. The particle-particle heat transfer is not accounted for in this study. The fluid-particle heat transfer coefficient $h$ was evaluated as follows:

$$
h=\frac{\mathrm{Nu}_{p} \cdot \lambda}{D_{p}},
$$

where $\lambda$ and $D_{p}$ are the thermal conductivity of gas-phase and the particle diameter, respectively.

The kinetics of coffee ground pyrolysis are described by a lumped kinetic model [27] simplified from detailed kinetics of cellulose, hemicellulose and lignin decomposition [36-39]. The reactions and their kinetic parameters have been progressively extended and updated based on the experimental data [27] and the model predictions adopting the pyrolysis kinetics have been verified in various reactor configurations including a drop tube reactor [23], a fixed-bed reactor [24], a fluidized bed reactor [15,24,32], a conical spouted bed reactor [32] operating in various fast pyrolysis conditions such as heating rates, reaction temperatures and gas and solid residence times. It has been shown that the maximum product yields as wells as the yield trends with temperature could be reasonably predicted.

It was assumed that each reference component decomposes through first-order reactions independently. The kinetic model includes 22 solid species and 28 gas species which constitute 25 reactions. The solid and gaseous species are listed in Tables 4 and 5, respectively. The kinetic parameters are summarized in Table 6. 
Table 4. Solid species in the simulation [27].

\begin{tabular}{|c|c|c|}
\hline Name & Formula & Note \\
\hline CELL & $\mathrm{C}_{6} \mathrm{H}_{10} \mathrm{O}_{5}$ & Cellulose \\
\hline HECELL & $\mathrm{C}_{5} \mathrm{H}_{8} \mathrm{O}_{4}$ & Hemicellulose \\
\hline LIGC & $\mathrm{C}_{15} \mathrm{H}_{14} \mathrm{O}_{4}$ & Lignin rich in carbon \\
\hline LIGH & $\mathrm{C}_{22} \mathrm{H}_{28} \mathrm{O}_{9}$ & Lignin rich in hydrogen \\
\hline LIGO & $\mathrm{C}_{20} \mathrm{H}_{22} \mathrm{O}_{10}$ & Lignin rich in oxygen \\
\hline TGL & $\mathrm{C}_{57} \mathrm{H}_{100} \mathrm{O}_{7}$ & Triglyceride \\
\hline ACQUA & $\mathrm{H}_{2} \mathrm{O}$ & Water \\
\hline ASH & ASH & Ash \\
\hline CELLA & $\mathrm{C}_{6} \mathrm{H}_{10} \mathrm{O}_{5}$ & \multirow{6}{*}{ Intermediate species } \\
\hline HCE1 & $\mathrm{C}_{5} \mathrm{H}_{8} \mathrm{O}_{4}$ & \\
\hline HCE2 & $\mathrm{C}_{5} \mathrm{H}_{8} \mathrm{O}_{4}$ & \\
\hline LIGCC & $\mathrm{C}_{15} \mathrm{H}_{14} \mathrm{O}_{4}$ & \\
\hline $\mathrm{LIGOH}$ & $\mathrm{C}_{19} \mathrm{H}_{22} \mathrm{O}_{8}$ & \\
\hline LIG & $\mathrm{C}_{11} \mathrm{H}_{12} \mathrm{O}_{4}$ & \\
\hline Char & $\mathrm{C}$ & Char \\
\hline $\mathrm{G}\{\mathrm{H} 2\}$ & $\mathrm{H}_{2}$ & \multirow{7}{*}{ Metaplastic } \\
\hline $\mathrm{G}\{\mathrm{CO}\}$ & $\mathrm{CO}$ & \\
\hline $\mathrm{G}\{\mathrm{CO} 2\}$ & $\mathrm{CO}_{2}$ & \\
\hline $\mathrm{G}\{\mathrm{COH} 2\}$ & $\mathrm{COH}_{2}$ & \\
\hline $\mathrm{G}\{\mathrm{CH} 4\}$ & $\mathrm{CH}_{4}{ }^{2}$ & \\
\hline $\mathrm{G}\{\mathrm{CH} 3 \mathrm{OH}\}$ & $\mathrm{CH}_{3} \mathrm{OH}$ & \\
\hline $\mathrm{G}\{\mathrm{C} 2 \mathrm{H} 4\}$ & $\mathrm{C}_{2} \mathrm{H}_{4}$ & \\
\hline
\end{tabular}

It is known that the ash content in the biomass can decrease the bio-crude oil yield by catalytic effect [27]. The major ash effect is the reduction of levoglucosan and xylan in favor of decomposition and dehydration products along with a char increase. The experimental data obtained in the VTT's pyrolyzer [40] showed that higher ash content leads to lower oil yield with higher water content. The decrease of oil yield as a function of ash content becomes almost negligible as the ash content are larger than $4 \mathrm{wt} \%$ [40]. To account for the ash effect, the simplified approach [27] was adopted and the kinetic parameters of a few selected reactions have been modified to maintain a flexible and simple mechanism. The reduction of levoglucosan and xylan along with char increase were taken into account by introducing a global ash factor as follows [27]:

$$
\mathrm{AF}=\tanh (\mathrm{ash} / 2) .
$$

It was assumed that catalytic effect is already completed for ash content of $5 \mathrm{wt} \%$ [27] and the ash factor (AF) was defined as Equation (3) where the value of AF ranges from zero to asymptotically 1. In this study, the ash content is $2.77 \%$ in coffee ground which leads to the ash factor of 0.882 . The activation energies of active cellulose decomposition $\left(E_{2}\right)$ and charification reaction $\left(E_{4}\right)$ are modified using AF as follows:

$$
\begin{gathered}
E_{2}=19100-600 \times(\mathrm{AF}-0.5)=18871[\mathrm{cal} / \mathrm{mol}] \\
E_{4}=31000-1000 \times(\mathrm{AF}-0.5)=30618[\mathrm{cal} / \mathrm{mol}] .
\end{gathered}
$$

The activation energies of the decomposition of hemicellulose intermediate (HCE1) are modified as follows:

$$
\begin{gathered}
E_{6}=11000-1000 \times(\mathrm{AF}-0.5)=10618[\mathrm{cal} / \mathrm{mol}] \\
E_{7}=3000-1000 \times(\mathrm{AF}-0.5)=2618[\mathrm{cal} / \mathrm{mol}] .
\end{gathered}
$$


Table 5. Gaseous species in the simulation [27].

\begin{tabular}{|c|c|c|}
\hline & Formula & Note \\
\hline \multirow{22}{*}{ Volatile (Condensable) } & $\mathrm{H}_{2} \mathrm{O}$ & water \\
\hline & $\mathrm{CH}_{2} \mathrm{O}$ & formaldehyde \\
\hline & $\mathrm{HCOOH}$ & formic-acid \\
\hline & $\mathrm{CH}_{3} \mathrm{OH}$ & methanol \\
\hline & $\mathrm{C}_{2} \mathrm{H}_{2} \mathrm{O}_{2}$ & glyoxal \\
\hline & $\mathrm{CH}_{3} \mathrm{CHO}$ & acetaldehyde \\
\hline & $\mathrm{CH}_{3} \mathrm{COOH}$ & acetic-acid \\
\hline & $\mathrm{C}_{2} \mathrm{H}_{4} \mathrm{O}_{2}$ & hydroxyacetaldehyde \\
\hline & $\mathrm{C}_{2} \mathrm{H}_{5} \mathrm{OH}$ & ethanol \\
\hline & $\mathrm{C}_{2} \mathrm{H}_{3} \mathrm{CHO}$ & acrolein \\
\hline & $\mathrm{C}_{2} \mathrm{H}_{5} \mathrm{CHO}$ & propionaldehyde \\
\hline & $\mathrm{C}_{3} \mathrm{H}_{6} \mathrm{O}_{2}$ & 3-hydroxypropanal \\
\hline & $\mathrm{C}_{5} \mathrm{H}_{4} \mathrm{O}_{2}$ & furan-2-carboxaldehyde(furfural) \\
\hline & $\mathrm{C}_{5} \mathrm{H}_{8} \mathrm{O}_{4}$ & xylofuranose \\
\hline & $\mathrm{C}_{6} \mathrm{H}_{5} \mathrm{OH}$ & phenol \\
\hline & $\mathrm{C}_{6} \mathrm{H}_{6} \mathrm{O}_{3}$ & 5-(hydroxymethyl)-furfural \\
\hline & $\mathrm{C}_{6} \mathrm{H}_{10} \mathrm{O}_{5}$ & levoglucosan \\
\hline & $\mathrm{C}_{6} \mathrm{H}_{5} \mathrm{OCH}_{3}$ & anisole \\
\hline & $\mathrm{C}_{9} \mathrm{H}_{10} \mathrm{O}_{2}$ & 4-(3-hydroxy-1-propenyl)phenol(pCoumaryl) \\
\hline & $\mathrm{C}_{11} \mathrm{H}_{12} \mathrm{O}_{4}$ & 3-(4-hydroxy-3_5-dimethoxyphenyl)acrylaldehyde \\
\hline & $\mathrm{C}_{13} \mathrm{H}_{22} \mathrm{O}_{2}$ & double_unsaturated_methyl_ester \\
\hline & $\mathrm{C}_{19} \mathrm{H}_{34} \mathrm{O}_{2}$ & methyl_linoleate \\
\hline \multirow{6}{*}{ Noncondensable } & $\mathrm{H}_{2}$ & hydrogen \\
\hline & $\mathrm{CO}$ & carbon-monoxide \\
\hline & $\mathrm{CO}_{2}$ & carbon-dioxide \\
\hline & $\mathrm{CH}_{4}$ & methane \\
\hline & $\mathrm{C}_{2} \mathrm{H}_{4}$ & ethylene \\
\hline & $\mathrm{C}$ & carbon \\
\hline
\end{tabular}

The feeding rate of coffee ground is $17.7 \mathrm{~kg} / \mathrm{h}$ and the sand flow rate is $662.6 \mathrm{~kg} / \mathrm{h}$. For computational efficiency, instead of tracking individual particles a parcel stream is adopted as a group of particles of same velocity. Per injection points of sand and coffee ground, the numbers of parcel streams are set at 100 . The temperature distribution inside the particle is assumed to be uniform. The particle size distributions of sand and coffee ground are shown in Figure 4 as cumulative distribution functions (CDF).

The simulation of the fast pyrolysis in a tilted-slide reactor is performed at various temperatures in a steady-state. The temperatures of injecting sands are 500,550, 600, $650{ }^{\circ} \mathrm{C}$ whereas the biomass temperature entering the reactor is $25^{\circ} \mathrm{C}$. The "reactor temperature" is determined at a specified location in the reactor as indicated in Figure 3, which corresponds to the thermocouple position in the experiment. The reactor temperatures will be used in the comparison with the experimental results and further analysis. 
Table 6. Kinetic mechanism of biomass pyrolysis [27].

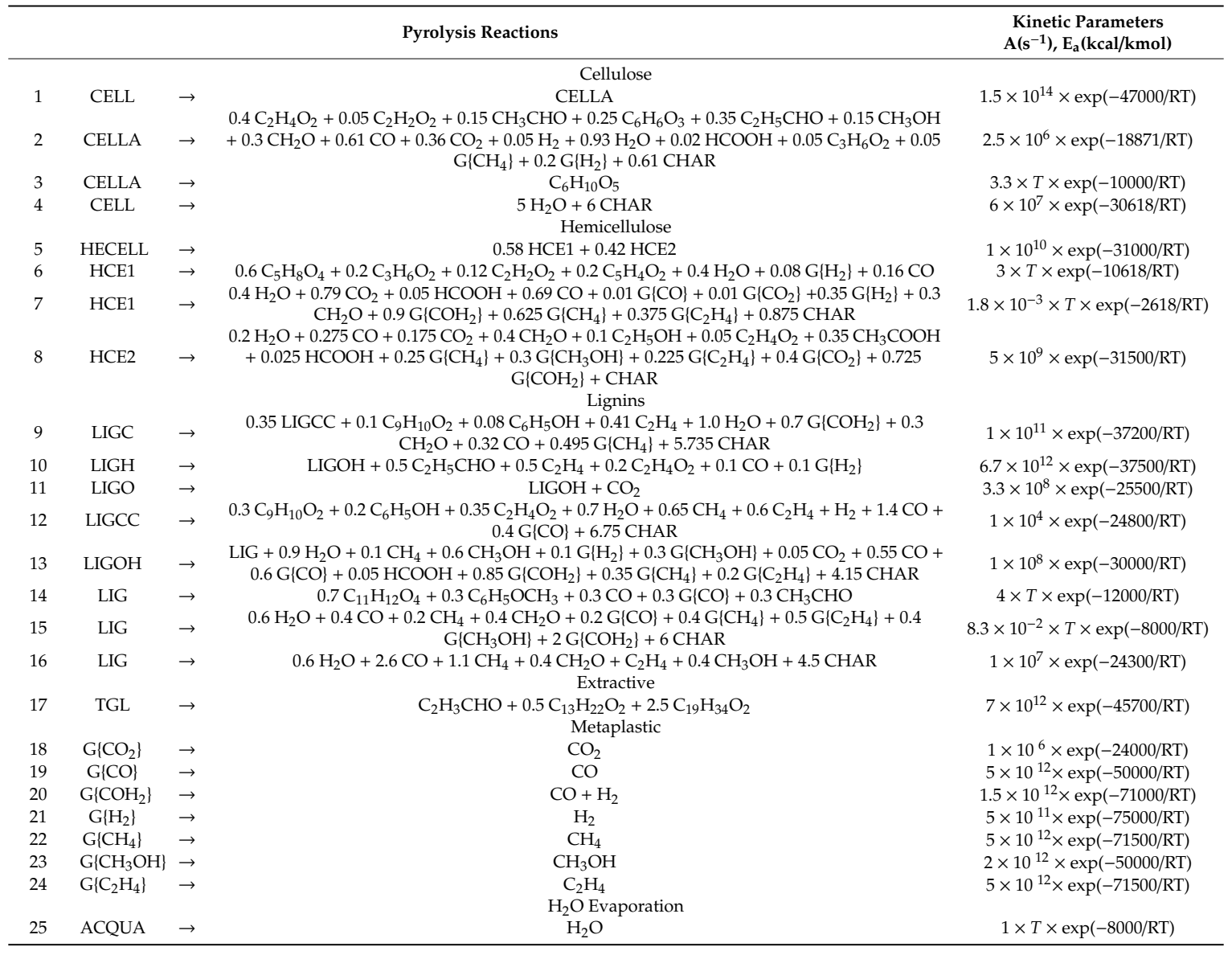

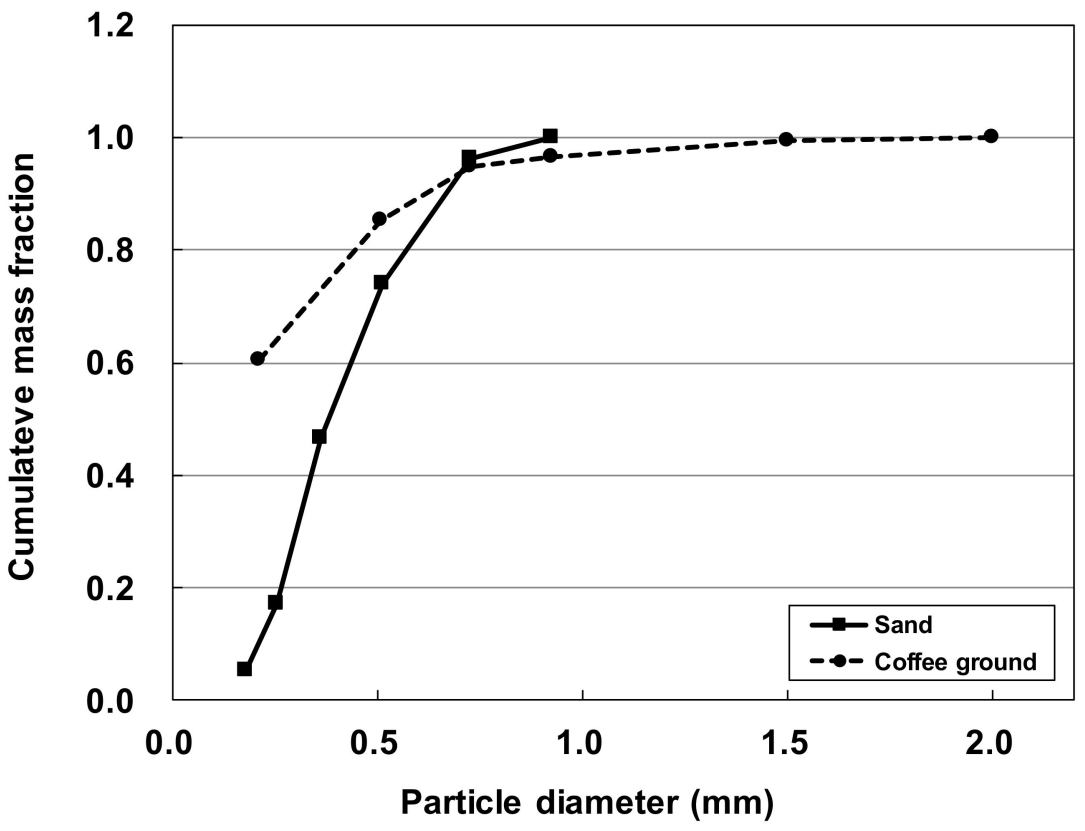

Figure 4. Particle size distributions of sand and coffee ground. 


\section{Results and Discussion}

\subsection{Overall Product Yields}

The yields of volatile, noncondensable gas and char in the simulation are evaluated as follows:

$$
\begin{gathered}
\text { Volatile yield }(\%)=\frac{\text { Mass flow rate of volatiles out of gas outlet }(\mathrm{kg} / \mathrm{s})}{\text { Biomass feeding rate at injector }(\mathrm{kg} / \mathrm{s})} \times 100 \\
\text { Noncondensable gas yield }(\%)=\frac{\text { Mass flow rate of noncondensable out of gas outlet }(\mathrm{kg} / \mathrm{s})}{\text { Biomass feeding rate at injector }(\mathrm{kg} / \mathrm{s})} \times 100 \\
\text { Char yield }(\%)=\frac{\text { Mass flow rate of solid residue out of reactor bottom and of gas outlet }(\mathrm{kg} / \mathrm{s})}{\text { Biomass feeding rate at injector }(\mathrm{kg} / \mathrm{s})} \times 100
\end{gathered}
$$

The product yields at various reactor temperatures are compared in Figure 5. The bio-crude yield from experiment [29] is also shown, which is denoted by 'Volatile (Experiment).' When only particle devolatilization is considered without secondary gas-phase reactions, the volatile yield increases continuously with increasing temperature as indicated by black dotted line in Figure 5. In practice, the volatile species from the fast pyrolysis can be further decomposed into smaller molecules which are typically noncondensable gases. In the previous study [31], the effect of the secondary tar cracking reactions has been considered in an indirect way because it is impractical to impose a comprehensive gas-phase chemistry to 3-D simulation directly. Using the surface averaged mass fractions at the gas outlet, a 1-D simulation was performed for a plug flow reactor [41] adopting the detailed gas-phase chemistry [32]. Because the detailed gas-phase reactions [32] consist of 507 species and 20239 reactions and it is not practical to impose them directly to the reactor simulation. But if it is possible to build up a simple kinetic mechanism which can reasonably predict tar cracking, it could be applied to the 3-D reactor simulation directly.

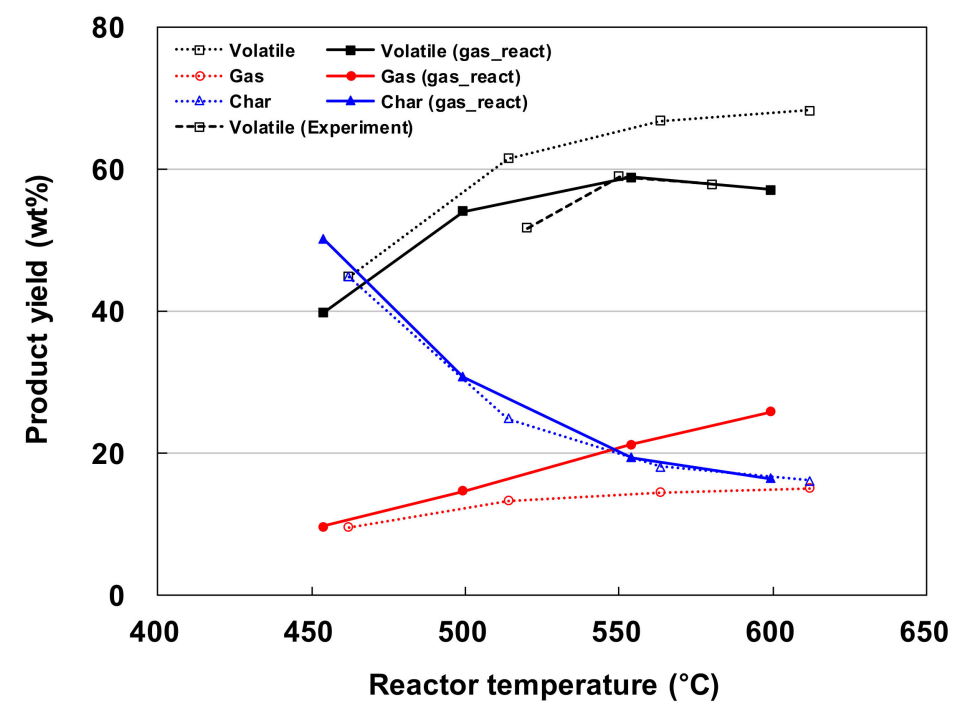

Figure 5. Product yields from fast pyrolysis of coffee ground at various reactor temperatures.

As a first step for establishing simplified kinetics, a calculation of plug flow reactor is performed starting from the mean composition at the reactor outlet at the reactor temperature of $563{ }^{\circ} \mathrm{C}$ to $t=5 \mathrm{~s}$ by using detailed gas-phase kinetics [32] similarly to the previous study [31]. When comparing the results from the 3-D reactor simulation without gas-phase reactions to 1-D plug flow reactor adopting detailed kinetics, the mass fractions of volatiles such as levoglucosan $\left(\mathrm{C}_{6} \mathrm{H}_{10} \mathrm{O}_{5}\right)$, xylofuranose $\left(\mathrm{C}_{5} \mathrm{H}_{8} \mathrm{O}_{4}\right)$ and methyl linoleate $\left(\mathrm{C}_{19} \mathrm{H}_{34} \mathrm{O}_{2}\right)$ and so forth, are quite larger than the results in plug flow reactor (pfr), while the mass fractions of noncondensable gases $\left(\mathrm{H}_{2}, \mathrm{CO}, \mathrm{CO}_{2}, \mathrm{CH}_{4}\right.$ and $\left.\mathrm{C}_{2} \mathrm{H}_{4}\right)$ are smaller. This result indicates that considerable amounts of volatile species are decomposed into lighter noncondensable 
gases by the secondary reactions. Based on this result, a simplified kinetics for secondary tar cracking are established following the methodology of Blondeau and Jeanmart [42], Mellen et al. [43] and Anca-Couce et al. [44] based on the global kinetic constants suggested by Park et al. [45]. The reactions listed in Table 7 share an identical activation energy $(E=108,000 \mathrm{~J} / \mathrm{mol})$. We note that carbon (C) is added as a product to some of the reactions for atomic balance. A preliminary test using the same pre-exponential factor $\left(A=4.28 \times 10^{6} \mathrm{~s}^{-1}\right)$ from Park et al. [45] for all reactions highly overpredict the reaction rate of tar cracking, leading to much smaller bio-crude oil yield. Therefore, the pre-exponential factors are adjusted to have a similar tar cracking trend with that calculated by the detailed chemistry in a 1-D plug flow reactor configuration. The adjusted pre-exponential factors in Table 7 are generally $A=1.2 \times 10^{5} \mathrm{~s}^{-1}$. We note that larger values are adopted for reactions 11 and 21 because the value of $A=1.2 \times 10^{5} \mathrm{~s}^{-1}$ highly overpredict the mass fractions $\mathrm{C}_{3} \mathrm{H}_{6} \mathrm{O}_{2}$ and $\mathrm{C}_{19} \mathrm{H}_{34} \mathrm{O}_{2}$. As shown in Figure 6, the differences in mass fractions from detailed and simplified kinetics are not significant and the simplified kinetics could be feasible to the reactor simulation. We note that although these simplified reactions are hypothetical and they have not been validated experimentally, it might be suggested that considering these reactions could improve the prediction of the bio-crude oil yield in the 3-D simulation without much computational cost.

Table 7. Secondary tar cracking reactions.

\begin{tabular}{|c|c|c|c|c|}
\hline \multicolumn{4}{|c|}{ Reactions } & \multirow{2}{*}{$\begin{array}{c}\text { Kinetic Parameters } \mathbf{A}\left(\mathbf{s}^{-1}\right), \mathbf{E}_{\mathbf{a}}(\mathbf{J} / \mathbf{m o l}) \\
1.2 \times 10^{5} \times \exp (-108000 / \mathrm{RT})\end{array}$} \\
\hline 1 & $\mathrm{CH}_{2} \mathrm{O}$ & $\rightarrow$ & $\mathrm{H}_{2}+\mathrm{CO}$ & \\
\hline 2 & $\mathrm{HCOOH}$ & $\rightarrow$ & $\mathrm{H}_{2}+\mathrm{CO}_{2}$ & $1.2 \times 10^{5} \times \exp (-108000 / \mathrm{RT})$ \\
\hline 3 & $\mathrm{CH}_{3} \mathrm{OH}$ & $\rightarrow$ & $1.5 \mathrm{H}_{2}+0.5 \mathrm{CO}+0.25 \mathrm{CO}_{2}+0.25 \mathrm{CH}_{4}$ & $1.2 \times 10^{5} \times \exp (-108000 / \mathrm{RT})$ \\
\hline 4 & $\mathrm{C}_{2} \mathrm{H}_{2} \mathrm{O}_{2}$ & $\rightarrow$ & $\mathrm{H}_{2}+2 \mathrm{CO}$ & $1.2 \times 10^{5} \times \exp (-108000 / \mathrm{RT})$ \\
\hline 5 & $\mathrm{CH}_{3} \mathrm{CHO}$ & $\rightarrow$ & $\mathrm{CO}+\mathrm{CH}_{4}$ & $1.2 \times 10^{5} \times \exp (-108000 / \mathrm{RT})$ \\
\hline 6 & $\mathrm{CH}_{3} \mathrm{COOH}$ & $\rightarrow$ & $1.5 \mathrm{H}_{2}+1.5 \mathrm{CO}+0.25 \mathrm{CO}_{2}+0.25 \mathrm{CH}_{4}$ & $1.2 \times 10^{5} \times \exp (-108000 / \mathrm{RT})$ \\
\hline 7 & $\mathrm{C}_{2} \mathrm{H}_{4} \mathrm{O}_{2}$ & $\rightarrow$ & $1.5 \mathrm{H}_{2}+1.5 \mathrm{CO}+0.25 \mathrm{CO}_{2}+0.25 \mathrm{CH}_{4}$ & $1.2 \times 10^{5} \times \exp (-108000 / \mathrm{RT})$ \\
\hline 8 & $\mathrm{C}_{2} \mathrm{H}_{5} \mathrm{OH}$ & $\rightarrow$ & $\mathrm{H}_{2}+\mathrm{CO}+\mathrm{CH}_{4}$ & $1.2 \times 10^{5} \times \exp (-108000 / \mathrm{RT})$ \\
\hline 9 & $\mathrm{C}_{2} \mathrm{H}_{3} \mathrm{CHO}$ & $\rightarrow$ & $\mathrm{CO}+\mathrm{C}_{2} \mathrm{H}_{4}$ & $1.2 \times 10^{5} \times \exp (-108000 / \mathrm{RT})$ \\
\hline 10 & $\mathrm{C}_{2} \mathrm{H}_{5} \mathrm{CHO}$ & $\rightarrow$ & $0.5 \mathrm{CO}_{2}+0.5 \mathrm{CH}_{4}+\mathrm{C}_{2} \mathrm{H}_{4}$ & $1.2 \times 10^{5} \times \exp (-108000 / \mathrm{RT})$ \\
\hline 11 & $\mathrm{C}_{3} \mathrm{H}_{6} \mathrm{O}_{2}$ & $\rightarrow$ & $\mathrm{H}_{2}+2 \mathrm{CO}+\mathrm{CH}_{4}$ & $1.2 \times 10^{7} \times \exp (-108000 / \mathrm{RT})$ \\
\hline 12 & $\mathrm{C}_{5} \mathrm{H}_{4} \mathrm{O}_{2}$ & $\rightarrow$ & $2 \mathrm{CO}+\mathrm{C}_{2} \mathrm{H}_{4}+\mathrm{C}$ & $1.2 \times 10^{5} \times \exp (-108000 / \mathrm{RT})$ \\
\hline 13 & $\mathrm{C}_{5} \mathrm{H}_{8} \mathrm{O}_{4}$ & $\rightarrow$ & $\mathrm{H}_{2}+2 \mathrm{CO}_{2}+1.5 \mathrm{C}_{2} \mathrm{H}_{4}$ & $1.2 \times 10^{5} \times \exp (-108000 / \mathrm{RT})$ \\
\hline 14 & $\mathrm{C}_{6} \mathrm{H}_{5} \mathrm{OH}$ & $\rightarrow$ & $\mathrm{CO}+0.5 \mathrm{CH}_{4}+\mathrm{C}_{2} \mathrm{H}_{4}+2.5 \mathrm{C}$ & $1.2 \times 10^{5} \times \exp (-108000 / \mathrm{RT})$ \\
\hline 15 & $\mathrm{C}_{6} \mathrm{H}_{6} \mathrm{O}_{3}$ & $\rightarrow$ & $3 \mathrm{CO}+1.5 \mathrm{C}_{2} \mathrm{H}_{4}$ & $1.2 \times 10^{5} \times \exp (-108000 / \mathrm{RT})$ \\
\hline 16 & $\mathrm{C}_{6} \mathrm{H}_{10} \mathrm{O}_{5}$ & $\rightarrow$ & $1.5 \mathrm{H}_{2}+2.5 \mathrm{CO}_{2}+1.75 \mathrm{C}_{2} \mathrm{H}_{4}$ & $1.2 \times 10^{5} \times \exp (-108000 / \mathrm{RT})$ \\
\hline 17 & $\mathrm{C}_{6} \mathrm{H}_{5} \mathrm{OCH}_{3}$ & $\rightarrow$ & $\mathrm{CO}+2 \mathrm{C}_{2} \mathrm{H}_{4}+2 \mathrm{C}$ & $1.2 \times 10^{5} \times \exp (-108000 / \mathrm{RT})$ \\
\hline 18 & $\mathrm{C}_{9} \mathrm{H}_{10} \mathrm{O}_{2}$ & $\rightarrow$ & $2 \mathrm{CO}+\mathrm{CH}_{4}+1.5 \mathrm{C}_{2} \mathrm{H}_{4}+3 \mathrm{C}$ & $1.2 \times 10^{5} \times \exp (-108000 / \mathrm{RT})$ \\
\hline 19 & $\mathrm{C}_{11} \mathrm{H}_{12} \mathrm{O}_{4}$ & $\rightarrow$ & $4 \mathrm{CO}+2 \mathrm{CH}_{4}+\mathrm{C}_{2} \mathrm{H}_{4}+3 \mathrm{C}$ & $1.2 \times 10^{5} \times \exp (-108000 / \mathrm{RT})$ \\
\hline 20 & $\mathrm{C}_{13} \mathrm{H}_{22} \mathrm{O}_{2}$ & $\rightarrow$ & $2 \mathrm{CO}+5.5 \mathrm{C}_{2} \mathrm{H}_{4}$ & $1.2 \times 10^{5} \times \exp (-108000 / \mathrm{RT})$ \\
\hline 21 & $\mathrm{C}_{19} \mathrm{H}_{34} \mathrm{O}_{2}$ & $\rightarrow$ & $2 \mathrm{C}_{2} \mathrm{H}_{3} \mathrm{CHO}+6.5 \mathrm{C}_{2} \mathrm{H}_{4}$ & $2.2 \times 10^{6} \times \exp (-108000 / \mathrm{RT})$ \\
\hline
\end{tabular}

The product yields imposing the simplified secondary reactions are indicated by solid lines in Figure 5 . We note that the reactor temperatures become smaller by about $10^{\circ} \mathrm{C}$ due to the presence of the gas-phase reactions. When the secondary reactions are implemented, the volatile yields decrease while the noncondensable gas yield increase particularly at higher temperature in comparison with the results without secondary reactions. The volatile yield shows the maximum value of $59 \%$ at the reactor temperature of $554{ }^{\circ} \mathrm{C}$, which agrees well with the experimental result. Also, the decreasing trend of volatile yield at higher temperature was almost identical with the experiment. Therefore, it can be said that the fast pyrolysis of coffee ground in a tilted-slide reactor could be predicted successfully at the temperatures higher than $550^{\circ} \mathrm{C}$. At lower temperatures the volatile yields were overpredicted and this might be due to the assumption of isothermal particle in this study. With this assumption, the center temperature of biomass particle rises as quickly as its surface temperature and the heating rate of biomass could be overpredicted especially at lower temperatures to promote the fast pyrolysis leading to higher volatile yield. The char yield varied little with the secondary reactions. 


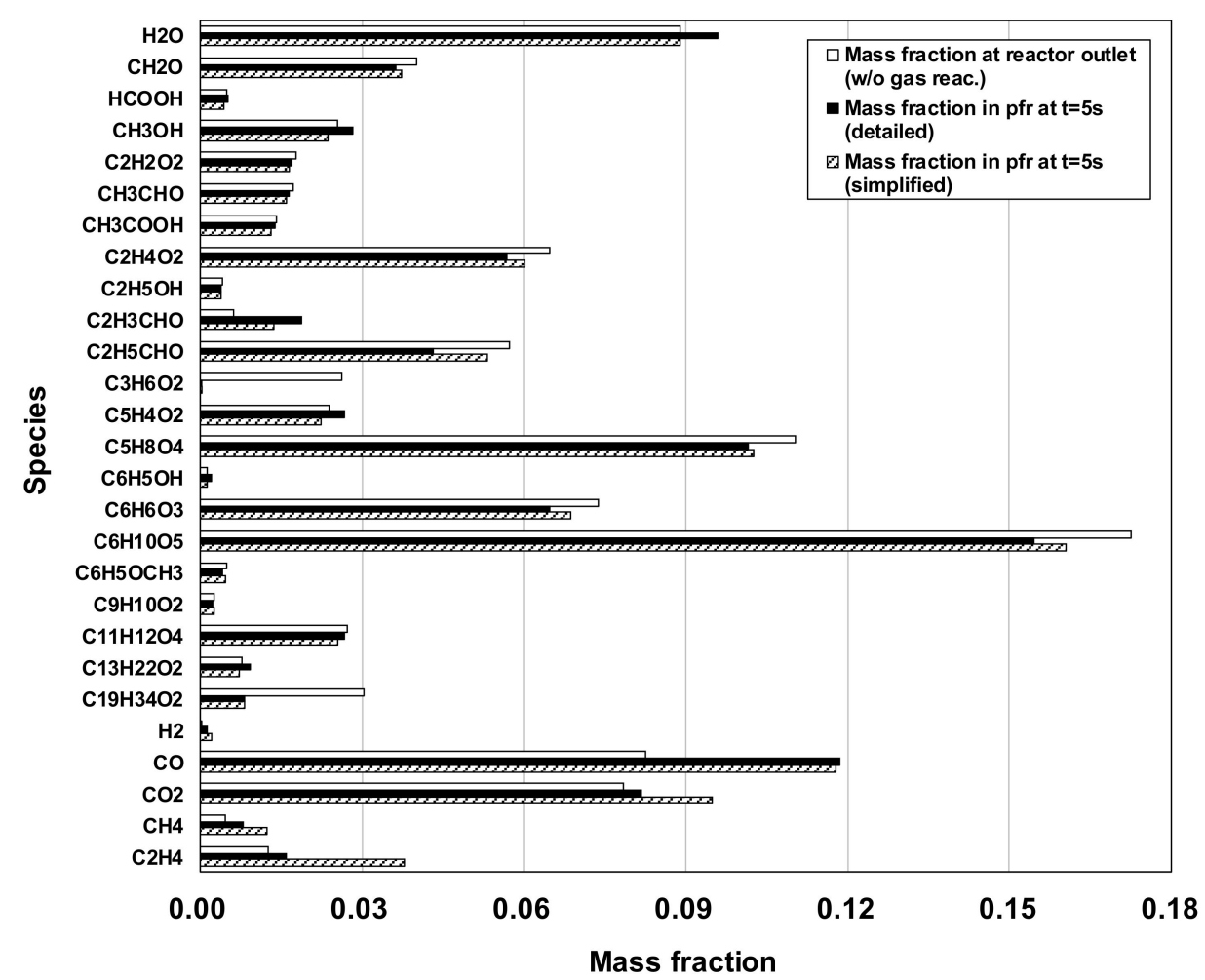

Figure 6. Mass fractions of gas-phase species calculated by detailed and simplified kinetics in plug-flow reactor $(t=5 \mathrm{~s})$ starting from the pyrolysis products from coffee ground at the reactor temperature of $563{ }^{\circ} \mathrm{C}$.

\subsection{Characteristics of Temperature, Pressure and Species Distributions}

The movements of sand and biomass particles are tracked after they were injected from the top of the reactor as shown in Figure $7 \mathrm{a}-\mathrm{c}$ at the reactor temperature of $554{ }^{\circ} \mathrm{C}$. The sand was injected at $600{ }^{\circ} \mathrm{C}$ and its temperature decreases while supplying the heat for fast pyrolysis. The temperature of coffee ground quickly increases up to the pyrolysis temperature while it is transported downward. The biomass heating rate was approximated to be $1000^{\circ} \mathrm{C} / \mathrm{s}$ which is within the range of fast pyrolysis conditions. The residence time of the biomass particle in the reactor is generally $5 \mathrm{~s}$ as shown in Figure 7c. The flow of the pyrolytic gas is visualized as streamlines in Figure 7d. The gas firstly rises from the reactor floor and recirculates along the reactor ceiling and then exits from the reactor. The secondary gas-phase reaction occurs during this procedure which decomposes volatiles into light gas species. The residence time of pyrolytic gas inside the reactor cannot be readily derived because the gas flow direction is not one-way differing from the fluidized-bed reactor as shown in Figure $7 \mathrm{~d}$. Alternatively, the vapor residence time can be approximated by comparing the mass fractions of volatile and gas at the reactor outlet with those of 1-D plug flow reactor (pfr). The solid lines in Figure S1 of the Supplementary Material show the evolution of the mass fractions of total volatile and gas species in pfr adopting the simplified secondary reactions. The initial composition was obtained from the surface averaged mass fractions at the gas outlet in the 3-D reactor simulation without secondary reactions. It can be observed that the volatile fraction decreases with time while the gas fraction increases due to the conversion of volatile to gas by tar cracking. The dotted lines in Figure S1 indicate the total volatile and gas fractions at the gas outlet in the 3-D reaction with secondary reactions. We note that the reactor simulation is performed in a steady-state and the time variable is not applied to the values. It can be found that the mass fractions of volatile and gas coincide with those of pfr calculation when the time in pfr is nearly $5 \mathrm{~s}$. Based on this result, the elapsed time for the secondary reactions can be approximated to be $5 \mathrm{~s}$ which could be equivalent to the gas residence time. 

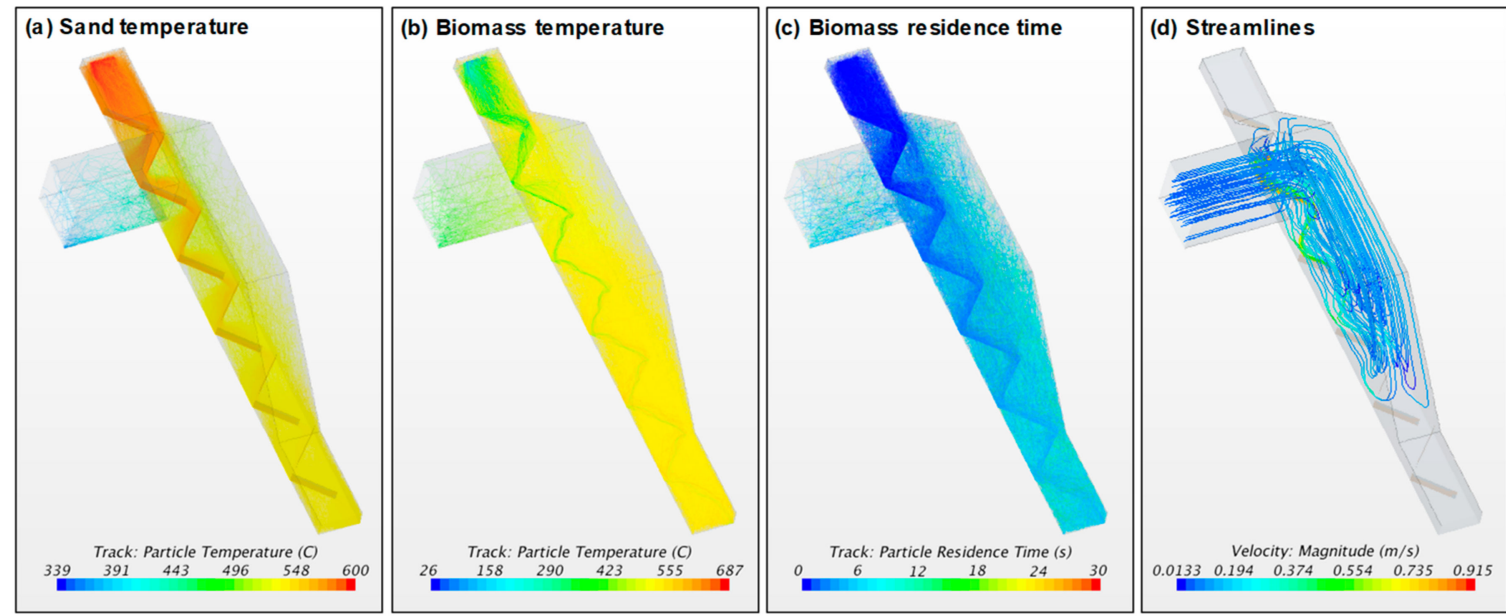

Figure 7. Particle behaviors and streamlines at the reactor temperature of $554{ }^{\circ} \mathrm{C}$.

Figure 8 shows the gas temperature, pressure and mass fraction distributions on the vertical plane section at the reactor temperature of $554{ }^{\circ} \mathrm{C}$. The temperature in Figure 8a descends in downward direction similarly to the sand temperature in Figure 7a. The surface averaged temperature at the reactor bottom is calculated to be $540{ }^{\circ} \mathrm{C}$ and this value is $14{ }^{\circ} \mathrm{C}$ smaller than the reactor temperature of $554{ }^{\circ} \mathrm{C}$. In the experiment [29], the reactor temperature was controlled to be 520,550 and $580{ }^{\circ} \mathrm{C}$. During the experiment, the sand inlet and outlet temperatures can be varied depending on the operating conditions such as the slit opening area in the sand hopper and the sand level at the reactor bottom. On average, the sand inlet temperature is measured to be $30 \sim 40{ }^{\circ} \mathrm{C}$ higher than the reactor temperature and the bottom temperature is $10 \sim 20^{\circ} \mathrm{C}$ smaller than the reactor temperature. In the simulation the sand inlet temperature is $48^{\circ} \mathrm{C}$ higher than the reactor temperature and the reactor temperature is $16^{\circ} \mathrm{C}$ higher than the reactor temperature. The temperature prediction could be considered in a reasonable range.

There can be shown a locally low temperature region near the location of gas outlet, which had not been observed in the previous study [31]. We note that the effect of the induced draft fan for the pyrolytic gas was accounted for in this study and this effect could result in the different temperature distribution in comparison with the previous study. The average pressure in the reactor is about $-16 \mathrm{~Pa}$ as shown in Figure 8b. We note that the reactor pressure had been maintained at about $-10 \sim-20 \mathrm{~Pa}$ in the experiment and the pressure could be predicted reasonably in the simulation.

The major pyrolysis products from cellulose (CELL), hemicellulose (HECELL), lignins (LIG-C, LIG-H, LIG-O) and extractive (TGL) are levoglucosan $\left(\mathrm{C}_{6} \mathrm{H}_{10} \mathrm{O}_{5}\right)$, xylofuranose $\left(\mathrm{C}_{5} \mathrm{H}_{8} \mathrm{O}_{4}\right)$, 3-(4-hydroxy-3,5-dimethoxyphenyl)acrylaldehyde $\left(\mathrm{C}_{11} \mathrm{H}_{12} \mathrm{O}_{4}\right)$ and methyl linoleate $\left(\mathrm{C}_{19} \mathrm{H}_{34} \mathrm{O}_{2}\right)$, respectively. The mass fraction distributions of these species are shown Figure $8 \mathrm{c}-\mathrm{f}$ at the reactor temperature of $554{ }^{\circ} \mathrm{C}$. The maximum mass fractions of $\mathrm{C}_{6} \mathrm{H}_{10} \mathrm{O}_{5}$ and $\mathrm{C}_{5} \mathrm{H}_{8} \mathrm{O}_{4}$ are located on upper side of the reactor, while the maximum value of $\mathrm{C}_{11} \mathrm{H}_{12} \mathrm{O}_{4}$ is near the reactor bottom. This result indicates a slower degradation of lignin than the cases of cellulose and hemicellulose, which had been exhibited by a thermogravimetric analysis [46]. The mass fraction of $\mathrm{C}_{19} \mathrm{H}_{34} \mathrm{O}_{2}$ is concentrated near the reactor top and this indicates a fast decomposition of extractive species in coffee ground at this temperature. The yields of individual pyrolysis products will be discussed in next subsection together with the pyrolysis progress inside the tilted-slide reactor. 

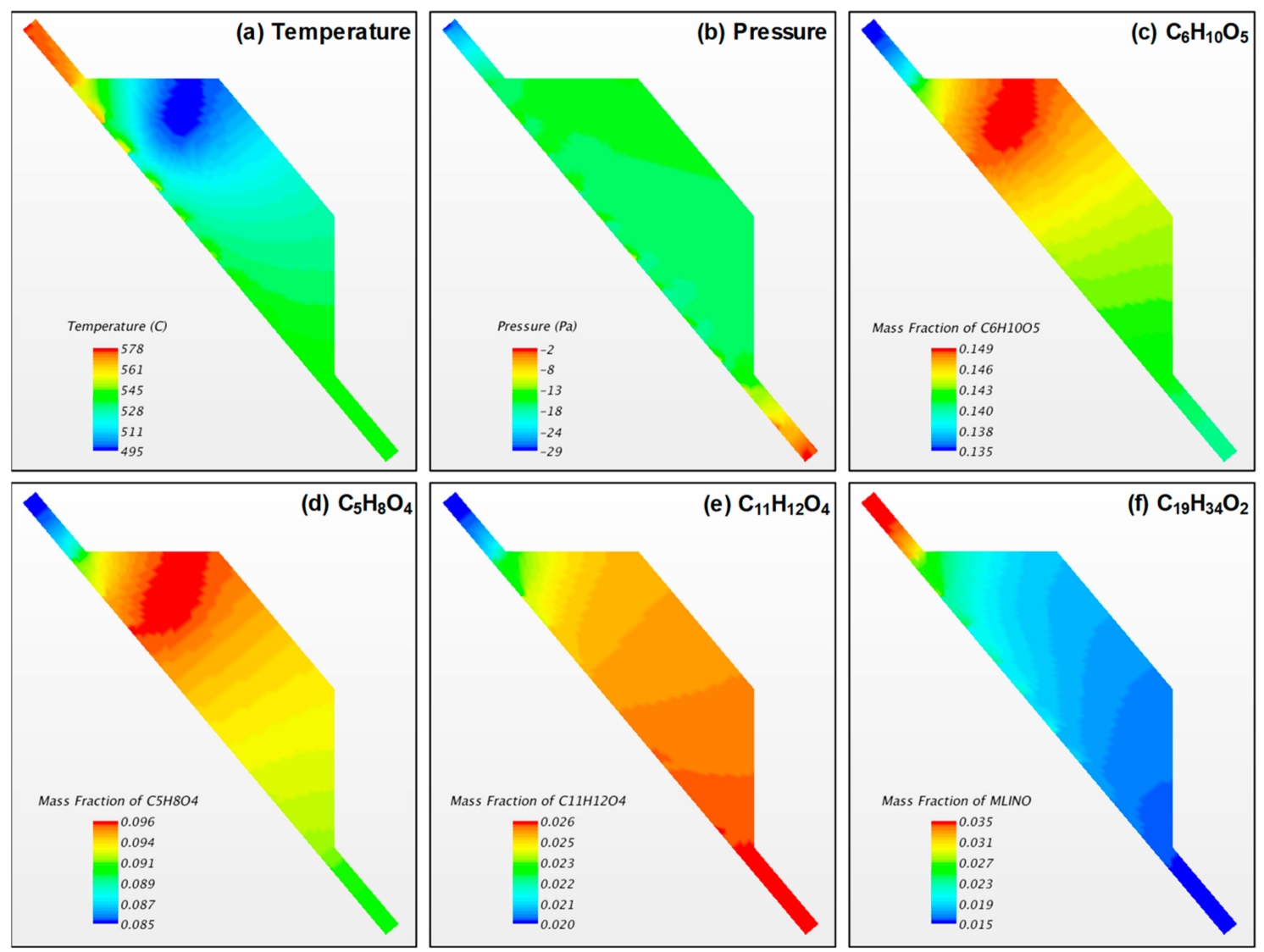

Figure 8. Temperature, pressure and mass fractions of major volatile species from cellulose, hemicellulose, lignin and extractives at the reactor temperature of $554{ }^{\circ} \mathrm{C}$.

\subsection{Species Yields and Pyrolysis Progress in the Tilted-Slide Reactor}

Figure 9 shows the yields of individual products from the fast pyrolysis of coffee ground in the tilted-slide reactor. For each species, the yields at various reactor temperatures are compared. The yields of noncondensable gases are shown in a separate subfigure. We note that the sum of the individual volatile or noncondensable gas yields in Figure 9 corresponds to the overall volatile or noncondensable gas yield in Figure 5. The $\mathrm{C}_{6} \mathrm{H}_{10} \mathrm{O}_{5}$ yield shows largest value in all pyrolysis products. This result is related to the largest mass fraction of cellulose in coffee ground as shown in Table 3. Focusing on the effect of reactor temperature, the $\mathrm{C}_{6} \mathrm{H}_{10} \mathrm{O}_{5}$ yield is maximum at $554{ }^{\circ} \mathrm{C}$ which corresponds to the maximum volatile yield and most of other volatile species also have similar trend with reactor temperature. The yield of individual noncondensable gas increase with reactor temperature and $\mathrm{CO}$ yields are largest.

Figure 10 shows the surface-integrated mass flow rates of pyrolyzed coffee ground particles on a cross-sections perpendicular to the reactor floor. The cross-sections are evenly arranged at $0.25 \mathrm{~m}$ intervals from the top of the reactor. The mass flow rates at $0 \mathrm{~m}$ and $2.55 \mathrm{~m}$ are biomass feeding rate at the injector $(17.7 \mathrm{~kg} / \mathrm{h})$ and outflow rate of solid residue at the reactor bottom, respectively. As the biomass particles descend along the reactor floor, they lose their mass while producing pyrolytic gas. At higher reactor temperature, the particle mass flow diminishes faster and the outflow rate at the bottom decreases resulting in a smaller char yield as shown in Figure 5. 


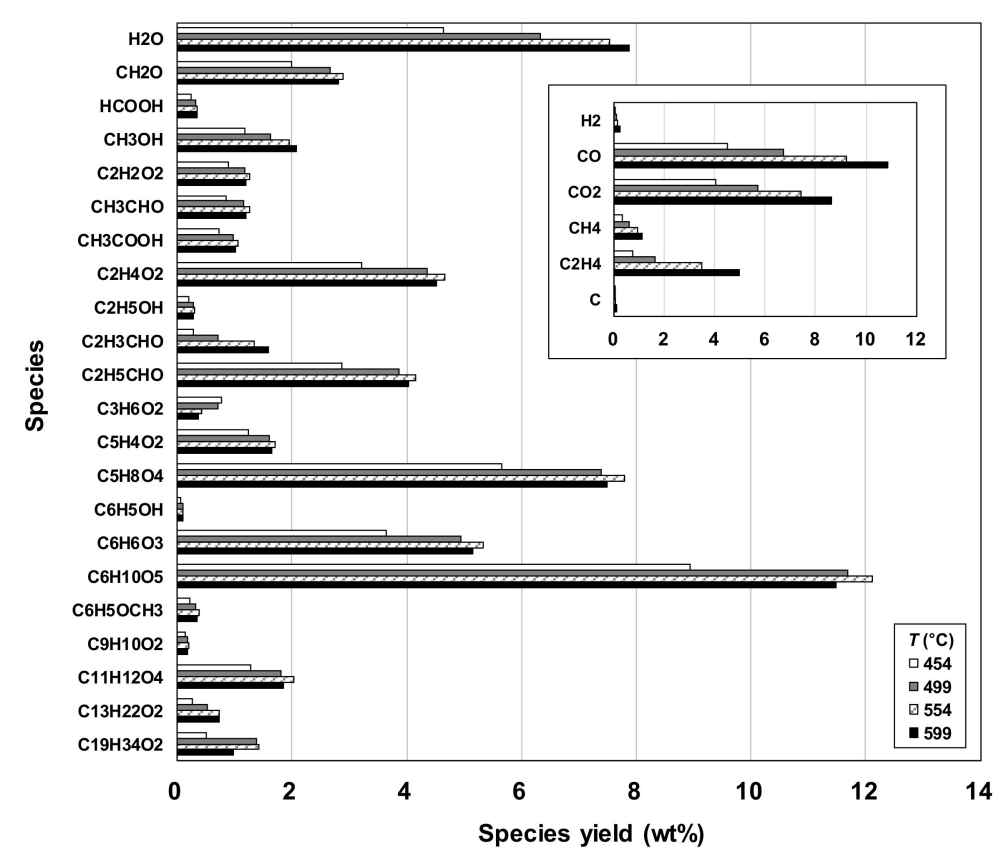

Figure 9. Species yields from fast pyrolysis of coffee ground at various reactor temperatures.

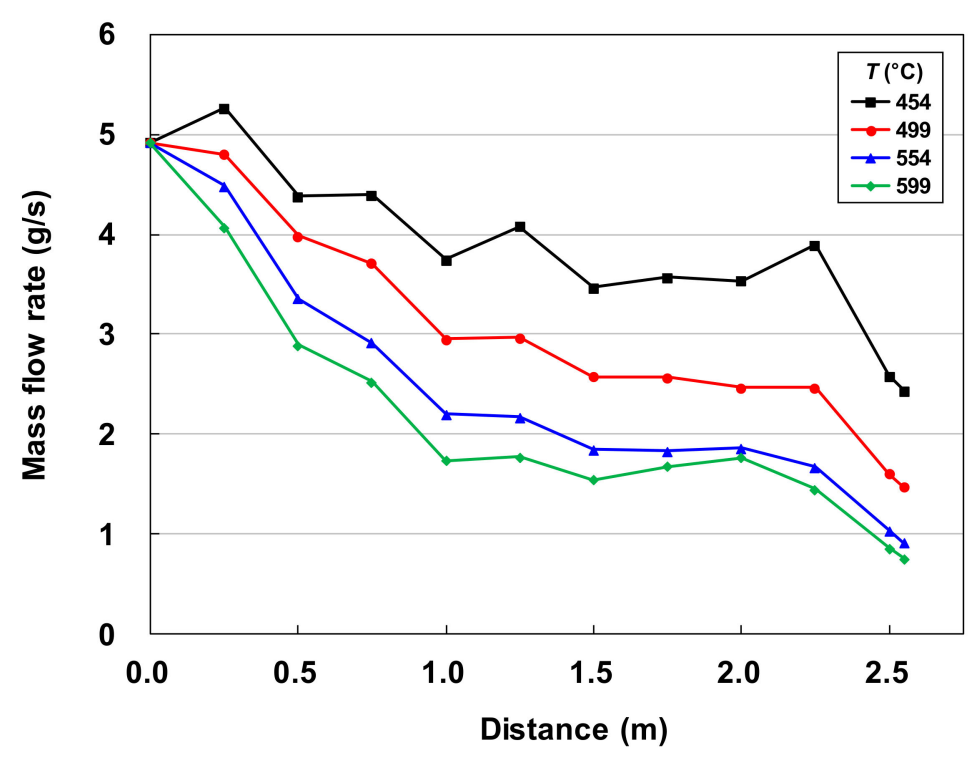

Figure 10. Mass flow rate of pyrolyzed particles along the distance from the top of the reactor.

Because the biomass components (cellulose, hemicellulose, lignin and extractive) have different kinetics of decomposition, so their devolatilization behaviors are also different. Figure 11 shows the decomposition behavior of each component at various reactor temperatures. At the lowest temperature of $454^{\circ} \mathrm{C}$, cellulose decreases almost linearly along the distance. The decompositions of hemicellulose and total lignin are relatively faster in the upper half of the reactor and then are slowed down in lower half of the reactor. But for each lignin component, LIGC is pyrolyzed rather slower than LIGH and LIGO. Triglyceride (TGL) is hardly decomposed and only small amount of it is decomposed near the reactor bottom. As the reactor temperature is increased to $499^{\circ} \mathrm{C}$, the trend of cellulose pyrolysis begins to be similar to those of hemicellulose and total lignin and the decompositions of TGL and LIGC becomes faster. At higher temperatures of 554 and $599^{\circ} \mathrm{C}$, the pyrolysis characteristics of the biomass components resemble each other as shown in Figure 11c-d. Also, the pyrolysis of TGL is more activated and most of TGL is decomposed down to the reactor bottom. Therefore, it can be known that for an effective TGL pyrolysis the reactor temperature should be above $500{ }^{\circ} \mathrm{C}$. 

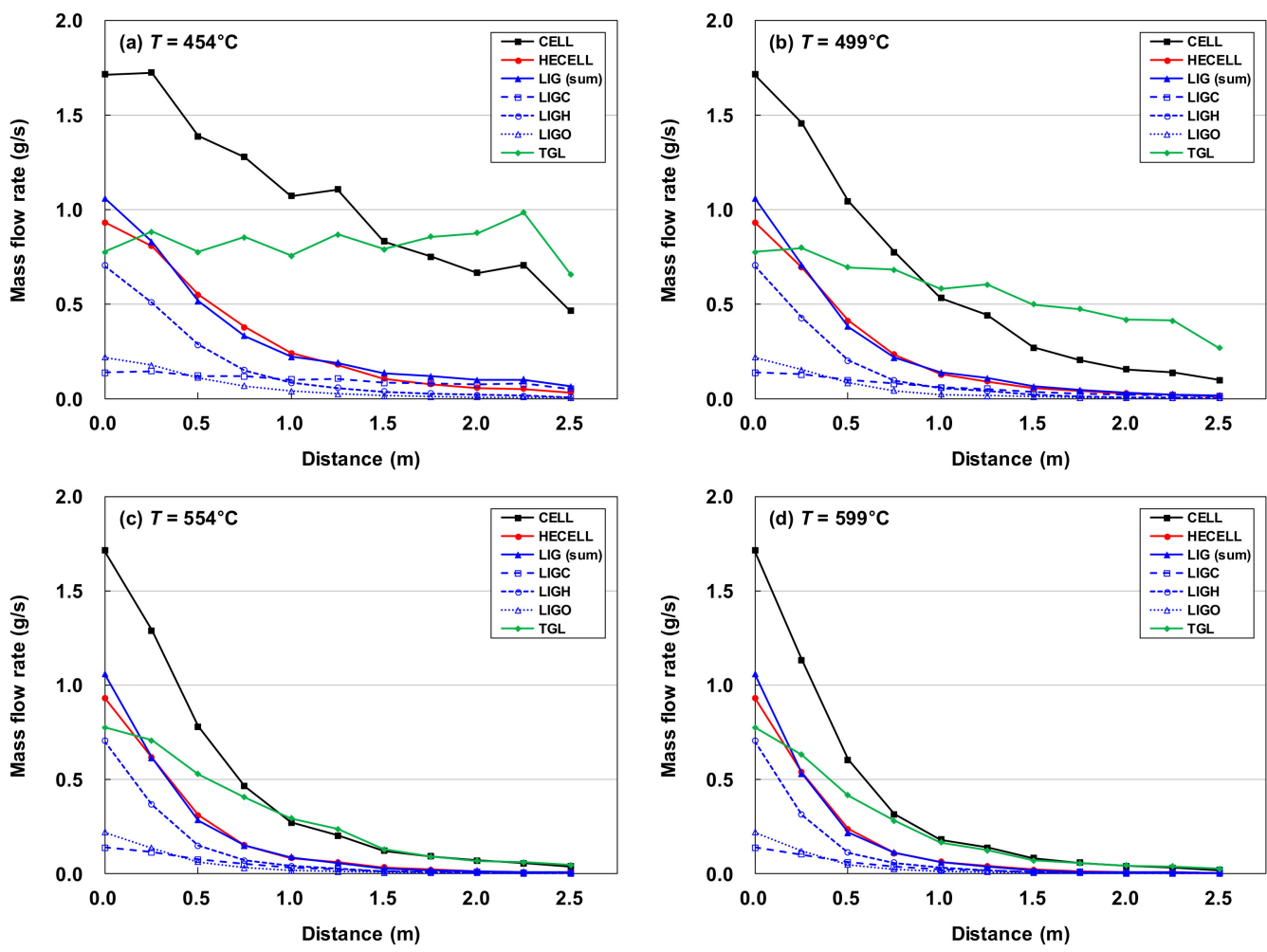

Figure 11. Mass flow rate of biomass components along the distance from the top of the reactor.

\section{Conclusions}

The fast pyrolysis of coffee ground in a tilted-slide reactor was simulated by a Lagrangian multiphase model. The biochemical composition of coffee ground was derived from the elemental analysis and the extended characterization method was adopted to account for the extractives in coffee ground. The volatile yields at various reactor temperatures were compared with those of experimental results. In the simulation without secondary gas-phase reaction, the volatile yield increased monotonically with reactor temperature while it turned to decrease at higher temperature in the experiment. The inclusion of secondary tar cracking reactions effectively decomposed the volatile species into light gas species, resulting in a decrease of volatile yield at high temperature. The maximum volatile yield in the simulation was $59 \%$ at the reactor temperature of $554{ }^{\circ} \mathrm{C}$ and this agreed well with the experimental results. Although the volatile yield in the simulation at lower temperature was larger than the experiment, the decreasing trend of volatile yield at high temperatures could be predicted well by inclusion of secondary tar cracking reactions. The spatial distributions of major volatile components indicated different pyrolysis behavior of each biomass component and the decomposition of each component was tracked along the distance from the reactor top to bottom. It was shown that triglyceride and lignin rich in carbon decomposed slower than other components at relatively lower temperatures. At the reactor temperatures above $500{ }^{\circ} \mathrm{C}$, their trend became similar to those of other components. It should be stressed that simplified secondary gas-phase reactions and the catalytic effect of ash were established in hypothetical manners and have not been validated experimentally. Nevertheless, we note that these strong simplifications have been adopted as an effective approach to reflect the experimental findings in the simulation and it might be expected that this aspect could be considered in a practical engineering point of view. Considering that various pyrolysis products are included in the simulation, the individual species might be compared with the measured concentration in a future study and it could be used for the improvement of the pyrolysis kinetics. Also, the simulation results are expected to be used as base design data for scaling up the pyrolysis plant. 
Supplementary Materials: The following are available online at http://www.mdpi.com/1996-1073/13/24/6605/s1, Figure S1: Mass fractions of total volatile and gas species in 1-D plug flow reactor (pfr) in comparison with the mass fractions at the gas outlet in the 3-D reactor simulation with secondary reactions.

Author Contributions: Conceptualization, Y.S.C. and S.K.C.; methodology, S.K.C.; investigation, S.K.C.; data curation, Y.W.J. and S.Y.H.; writing—original draft preparation, S.K.C.; visualization, Q.V.N.; supervision, Y.S.C.; project administration, Y.S.C. All authors have read and agreed to the published version of the manuscript.

Funding: This work was supported by the "Development of Rooftop WISE Farm Technologies Utilizing Building Energy" project (NK225B) of the Korea Institute of Machinery and Materials under the auspices of the Korea government (MSIT), Republic of Korea. This work was also supported by the National Research Council of Science \& Technology (NST) grant by the Korea government (MSIT) No. CAP-16-05-KIMM. The authors gratefully acknowledge this support.

Conflicts of Interest: The authors declare no conflict of interest.

\section{References}

1. Bridgwater, A.V.; Meier, D.; Radlein, D. An overview of fast pyrolysis of biomass. Org. Geochem. 1999, 30, 1479-1493. [CrossRef]

2. Mohan, D.; Pittman, C.U.; Steele, P.H. Pyrolysis of wood/biomass for bio-oil: A critical review. Energy Fuels 2006, 20, 848-889. [CrossRef]

3. Lu, Q.; Li, W.Z.; Zhu, X.F. Overview of fuel properties of biomass fast pyrolysis oils. Energy Convers. Manag. 2009, 50, 1376-1383. [CrossRef]

4. Bridgwater, A.V. Review of fast pyrolysis of biomass and product upgrading. Biomass Bioenergy 2012, 38, 68-94. [CrossRef]

5. Bok, J.P.; Choi, H.S.; Choi, J.W.; Choi, Y.S. Fast pyrolysis of Miscanthus sinensis in fluidized bed reactors: Characteristics of product yields and biocrude oil quality. Energy 2013, 60, 44-52. [CrossRef]

6. Wagenaar, B.M.; Prins, W.; van Swaaij, W.P.M. Pyrolysis of biomass in the rotating cone reactor: Modelling and experimental justification. Chem. Eng. Sci. 1994, 49, 5109-5126. [CrossRef]

7. Fernandez-Akarregi, A.R.; Makibar, J.; Lopez, G.; Amutio, M.; Olazar, M. Design and operation of a conical spouted bed reactor pilot plant (25 kg/h) for biomass fast pyrolysis. Fuel Process. Technol. 2013, 112, 48-56. [CrossRef]

8. Ingram, L.; Mohan, D.; Bricka, M.; Steele, P.; Strobel, D.; Mitchell, B.; Mohammad, J.; Cantrell, K.; Pittman, C.U., Jr. Pyrolysis of Wood and Bark in an Auger Reactor: Physical Properties and Chemical Analysis of the Produced Bio-oils Pyrolysis of Wood and Bark in an Auger Reactor: Physical Properties and Chemical Analysis of the Produced Bio-oils. Energy Fuels 2008, 22, 614-625. [CrossRef]

9. Choi, Y.S.; Choi, S.K.; Jeong, Y.W. Development of a tilted-slide reactor for the fast pyrolysis of biomass. Environ. Prog. Sustain. Energy 2014, 33. [CrossRef]

10. Lathouwers, D.; Bellan, J. Modeling of dense gas-solid reactive mixtures applied to biomass pyrolysis in a fluidized bed. Int. J. Multiph. Flow 2001, 27, 2155-2187. [CrossRef]

11. Lathouwers, D.; Bellan, J. Yield Optimization and Scaling of Fluidized Beds for Tar Production from Biomass. Energy Fuels 2001, 15, 1247-1262. [CrossRef]

12. Xue, Q.; Heindel, T.J.; Fox, R.O. A CFD model for biomass fast pyrolysis in fluidized-bed reactors. Chem. Eng. Sci. 2011, 66, 2440-2452. [CrossRef]

13. Xue, Q.; Dalluge, D.; Heindel, T.J.; Fox, R.O.; Brown, R.C. Experimental validation and CFD modeling study of biomass fast pyrolysis in fluidized-bed reactors. Fuel 2012, 97, 757-769. [CrossRef]

14. Ranganathan, P.; Gu, S. Bioresource Technology Computational fluid dynamics modelling of biomass fast pyrolysis in fluidised bed reactors, focusing different kinetic schemes. Bioresour. Technol. 2016, 213, 333-341. [CrossRef] [PubMed]

15. Brandão, F.L.; Verissimo, G.L.; Leite, M.A.H.; Leiroz, A.J.K.; Cruz, M.E. Computational Study of Sugarcane Bagasse Pyrolysis Modeling in a Bubbling Fluidized Bed Reactor. Energy Fuels 2018, 32, 1711-1723. [CrossRef]

16. Sia, S.Q.; Wang, W.C. Numerical simulations of fluidized bed fast pyrolysis of biomass through computational fluid dynamics. Renew. Energy 2020, 155, 248-256. [CrossRef]

17. Shuangning, X.; Zhihe, L.; Baoming, L.; Weiming, Y.; Xueyuan, B. Devolatilization characteristics of biomass at flash heating rate. Fuel 2006, 85, 664-670. [CrossRef] 
18. Sun, S.; Tian, H.; Zhao, Y.; Sun, R.; Zhou, H. Experimental and numerical study of biomass flash pyrolysis in an entrained flow reactor. Bioresour. Technol. 2010, 101, 3678-3684. [CrossRef]

19. Richter, A.; Vascellari, M.; Nikrityuk, P.A.; Hasse, C. Detailed analysis of reacting particles in an entrained-flow gasifier. Fuel Process. Technol. 2016, 144, 95-108. [CrossRef]

20. Lopez, G.; Alvarez, J.; Amutio, M.; Hooshdaran, B.; Cortazar, M.; Haghshenasfard, M.; Hosseini, S.H.; Olazar, M. Kinetic modeling and experimental validation of biomass fast pyrolysis in a conical spouted bed reactor. Chem. Eng. J. 2019, 373, 677-686. [CrossRef]

21. Park, H.C.; Choi, H.S. Fast pyrolysis of biomass in a spouted bed reactor: Hydrodynamics, heat transfer and chemical reaction. Renew. Energy 2019, 143, 1268-1284. [CrossRef]

22. Moliner, C.; Marchelli, F.; Spanachi, N.; Martinez-Felipe, A.; Bosio, B.; Arato, E. CFD simulation of a spouted bed: Comparison between the Discrete Element Method (DEM) and the Two Fluid Model (TFM). Chem. Eng. J. 2019, 377, 120466. [CrossRef]

23. Ranzi, E.; Cuoci, A.; Faravelli, T.; Frassoldati, A.; Migliavacca, G.; Pierucci, S.; Sommariva, S. Chemical kinetics of biomass pyrolysis. Energy Fuels 2008, 22, 4292-4300. [CrossRef]

24. Calonaci, M.; Grana, R.; Barker Hemings, E.; Bozzano, G.; Dente, M.; Ranzi, E. Comprehensive kinetic modeling study of bio-oil formation from fast pyrolysis of biomass. Energy Fuels 2010, 24, 5727-5734. [CrossRef]

25. Corbetta, M.; Frassoldati, A.; Bennadji, H.; Smith, K.; Serapiglia, M.J.; Gauthier, G.; Melkior, T.; Ranzi, E.; Fisher, E.M. Pyrolysis of centimeter-scale woody biomass particles: Kinetic modeling and experimental validation. Energy Fuels 2014, 28, 3884-3898. [CrossRef]

26. Debiagi, P.E.A.; Pecchi, C.; Gentile, G.; Frassoldati, A.; Cuoci, A.; Faravelli, T.; Ranzi, E. Extractives Extend the Applicability of Multistep Kinetic Scheme of Biomass Pyrolysis. Energy Fuels 2015, 29, 6544-6555. [CrossRef]

27. Ranzi, E.; Debiagi, P.E.A.; Frassoldati, A. Mathematical Modeling of Fast Biomass Pyrolysis and Bio-Oil Formation. Note I: Kinetic Mechanism of Biomass Pyrolysis. ACS Sustain. Chem. Eng. 2017, 5, 2867-2881. [CrossRef]

28. Bok, J.P.; Choi, Y.S.; Choi, S.K.; Jeong, Y.W. Fast pyrolysis of Douglas fir by using tilted-slide reactor andcharacteristics of biocrude-oil fractions. Renew. Energy 2014, 65, 7-13. [CrossRef]

29. Choi, Y.S.; Choi, S.K.; Kim, S.J.; Jeong, Y.W.; Soysa, R.; Rahman, T. Fast pyrolysis of coffee ground in a tilted-slide reactor and characteristics of biocrude oil. Environ. Prog. Sustain. Energy 2017, 36, 655-661. [CrossRef]

30. Choi, Y.; Choi, S.; Kim, S.; Han, S.; Jeong, Y. Effect of Biomass Particle Size on the Fast Pyrolysis Characteristics of Palm Kernel Shell to Produce Biocrude-oil. New Renew. Energy 2017, 13, 55-63. [CrossRef]

31. Choi, S.K.; Choi, Y.S.; Kim, S.J.; Han, S.Y.; Jeong, Y.W.; Kwon, Y.S.; Van Nguyen, Q. Simulation of a tilted-slide reactor for the fast pyrolysis of biomass. Biomass Bioenergy 2019, 126, 94-105. [CrossRef]

32. Ranzi, E.; Debiagi, P.E.A.; Frassoldati, A. Mathematical Modeling of Fast Biomass Pyrolysis and Bio-Oil Formation. Note II: Secondary Gas-Phase Reactions and Bio-Oil Formation. ACS Sustain. Chem. Eng. 2017, 5, 2882-2896. [CrossRef]

33. USDA. Foreign Agricultural Service Coffee: World Markets and Trade; USDA: Washington, DC, USA, 2019; pp. 1-9. Available online: https://www.fas.usda.gov/data/coffee-world-markets-and-trade (accessed on 29 April 2020).

34. CD-adapco User Guide. In STAR-CCM+ Version 9.06; CD-adapco: New York, NY, USA, 2014.

35. Gunn, D.J. Transfer of heat or mass to particles in fixed and fluidised beds. Int. J. Heat Mass Transf. 1978, 21, 467-476. [CrossRef]

36. Seshadri, V.; Westmoreland, P.R. Concerted reactions and mechanism of glucose pyrolysis and implications for cellulose kinetics. J. Phys. Chem. A 2012, 116, 11997-12013. [CrossRef] [PubMed]

37. Vinu, R.; Broadbelt, L.J. A mechanistic model of fast pyrolysis of glucose-based carbohydrates to predict bio-oil composition. Energy Environ. Sci. 2012, 5, 9808-9826. [CrossRef]

38. Zhou, X.; Nolte, M.W.; Mayes, H.B.; Shanks, B.H.; Broadbelt, L.J. Experimental and mechanistic modeling of fast pyrolysis of neat glucose-based carbohydrates. 1. Experiments and development of a detailed mechanistic model. Ind. Eng. Chem. Res. 2014, 53, 13274-13289. [CrossRef]

39. Faravelli, T.; Frassoldati, A.; Migliavacca, G.; Ranzi, E. Detailed kinetic modeling of the thermal degradation of lignins. Biomass Bioenergy 2010, 34, 290-301. [CrossRef] 
40. Oasmaa, A.; Sundqvist, T.; Kuoppala, E.; Garcia-Perez, M.; Solantausta, Y.; Lindfors, C.; Paasikallio, V. Controlling the phase stability of biomass fast pyrolysis bio-oils. Energy Fuels 2015, 29, 4373-4381. [CrossRef]

41. Goodwin, D.G.; Speth, R.L.; Moffat, H.K.; Weber, B.W. Cantera: An Object-Oriented Software Toolkit for Chemical Kinetics, Thermodynamics, and Transport Processes. Available online: https://www.cantera.org (accessed on 9 September 2020).

42. Blondeau, J.; Jeanmart, H. Biomass pyrolysis at high temperatures: Prediction of gaseous species yields from an anisotropic particle. Biomass Bioenergy 2012, 41, 107-121. [CrossRef]

43. Mellin, P.; Kantarelis, E.; Yang, W. Computational fluid dynamics modeling of biomass fast pyrolysis in a fluidized bed reactor, using a comprehensive chemistry scheme. Fuel 2014, 117, 704-715. [CrossRef]

44. Anca-Couce, A.; Sommersacher, P.; Scharler, R. Online experiments and modelling with a detailed reaction scheme of single particle biomass pyrolysis. J. Anal. Appl. Pyrolysis 2017, 127, 411-425. [CrossRef]

45. Park, W.C.; Atreya, A.; Baum, H.R. Experimental and theoretical investigation of heat and mass transfer processes during wood pyrolysis. Combust. Flame 2010, 157, 481-494. [CrossRef]

46. Yang, H.; Yan, R.; Chen, H.; Zheng, C.; Lee, D.H.; Liang, D.T. In-depth investigation of biomass pyrolysis based on three major components: Hemicellulose, cellulose and lignin. Energy Fuels 2006, 20, 388-393. [CrossRef]

Publisher's Note: MDPI stays neutral with regard to jurisdictional claims in published maps and institutional affiliations.

(C) 2020 by the authors. Licensee MDPI, Basel, Switzerland. This article is an open access article distributed under the terms and conditions of the Creative Commons Attribution (CC BY) license (http://creativecommons.org/licenses/by/4.0/). 